\title{
高軸力を受ける鉄筋コンクリート柱の曲げ靱性改善手法に 関する一提案 \\ A PROPOSAL OF A NEW METHOD TO IMPROVE FLEXURAL DUCTILITY FOR REINFORCED CONCRETE COLUMN SUBJECT \\ TO HIGH AXIAL LOAD
}

\author{
堀田久 人*, 滝口克已** \\ Hisato HOTTA and Katsuki TAKIGUCHI
}

\begin{abstract}
In this paper, a new method to improve flexural ductility of reinforced concrete column is proposed. This new method is to add peculiar longitudinal bars symmetrically wrought so as to be effective against compression but not effective against tension. The members with those additional bars may have the same performance as the ones in which the longitudinal bars are arranged eccentrically presented in the previous paper ${ }^{1)}$ while they keep symmetrical section required to the interior column. Their seismic performance was investigated empirically as they were compared with the ordinary members'. According to the authors' expectation, the proposed method greatly improves the ductility of the members.
\end{abstract}

\section{Keywords:reinforced concrete, interior column, high axial load, flexural ductility, severed reinforcing bar 鉄筋コンクリート，内柱，高軸力，曲け靶性，切断鉄筋}

\section{1. 序}

鉄筋コンクリート構造は，極言すれば，脆性材料であるコンク リートを破壊させず，鉄筋を破壊（塑性化）させることで靬性能を 確保した構造である。梁部材では，引張り鉄筋比を釣り合い鉄筋比 以下に制限することで, 比較的容易に上述の事柄を実現し得ている が，柱部材では，軸力比によっては必ずしも引張り鉄筋の塑性化に よるエネルギー吸収能力を十分発揮させているとは言い難く, 軸力 比が大きくなる程, 変形能力がそしくなるという欠点を有している。 しかしながら, 現行の粘りに期待した設計法では, 激震時に最下層 の柱脚の曲げ降伏を許容していることからこの部位の軸力保持能 力まで含めた靭性能が建物全体の変形能力を規定しているといって 屯過言ではなく，柱の鞄性能を十分確保する意義は大きい。 柱の曲げ変形能力を確保する手段としては, 従来は専ら, いわゆ るコンファインドコンクリートといった圧縮側のコンクリート自体

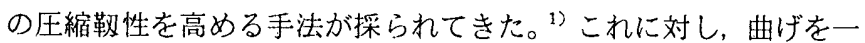
方向に限定して考えれば, 圧縮側の鉄筋のみを増加させ, 断面を偏 断面之することも，コンクリートの圧縮力負担を圧縮鉄筋で低減し 得るので, 有効な靬性能改善手法になり得る。偏心配筋した柱の曲

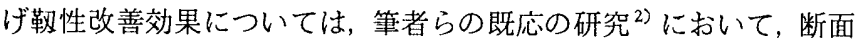
解析及び，定軸力下における曲げ試験により確認済みである。
もっとも、「曲げを一方向に限定して考えれば」と断り書きしたよ うに，柱，特に内柱は正負交番の曲げに抵抗しなければならないの で，断面には対称性が要求されるのが一般である。しかし，ここで 仮に「圧縮力には抵抗するが，引張り力を負担しない鉄筋」が存在 すれば，話は変わってくる。即ち，通常の鉄筋に加え，この特殊筋 を断面に刘称配筋することで，任意方向の曲げに対して断面の対称 性を保持しつつ，偏心配筋の効果が狙えることになる。以上が，本 研究の発想の背景である。

具体的には，Fig. 1 に示すように一部の鉄筋を危険断面近傍で切

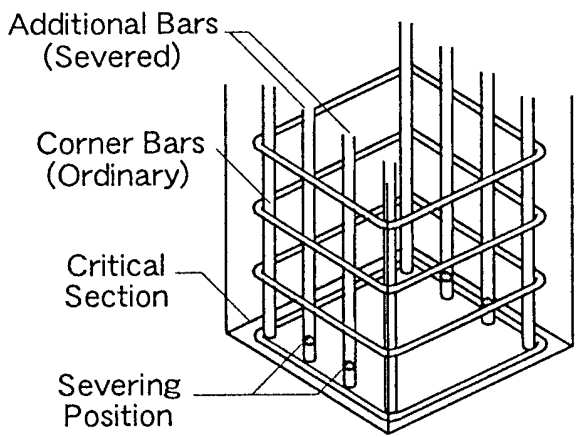

Fig. 1 Outline of proposed method
* 東京工業大学工学部建築学科 助教授 - 博士 (工学)

** 東京工業大学工学部建築学科 教授. 工博
Assoc. Prof., Dept. of Architecture and Building Eng., Faculty of Eng., Tokyo Institute of Technology, Dr. Eng.

Prof., Dept. of Architecture and Building Eng., Faculty of Eng., Tokyo Institute of Technology, Dr. Eng. 
断し, 圧縮力は切断された鉄筋同士の接触面圧によって伝達される ことを目論んでいる。実際には, 施工性を考虑し，一度切断した面 を旋盤で切削加エした後, リブ部の点溶接により再度接合したもの を用いる。こうして加工した鉄筋は，点溶接部の冷却収縮により接 触面に圧縮応力が, 溶着部に引張り応力が作用しており, 引張り力 に対して早期に破断することが期待される。問題は，目論見どおり， 偏心配筋の効果が現れるまで, 即ち, 塑性流れが生じるまでの圧縮 力伝達能力があるかどうか，及び，切断位置で鉄筋の太柄作用がな くなること，あるいは，断面性能が急変することの悪影響がないか どうか等である。本論文は，上記の事柄を実験的に検討するととも に, 通常配筋の柱モデルとの比較実験を通して提案手法の有效性に ついて論じたものである。

\section{2. 切断筋の引張り及び圧縮性能}

Fig. 2 に切断鉄筋の加工手順を示す。鉄筋は電動のこぎりで材軸 にほぼ垂直に切断した後, 切断面ができるだけ平滑になるように旋 盤で切削処理を施す。切断面を再び突き合わせ，万力で固定し，リ ブ部 2 箇所を点溶接により再び接合する。切断面の面仕上げは, 鏡 面加工からは程遠い程度の粗い仕上がりである。

再接合した鉄筋の引張り試験結果を Table 1 に示す。鉄筋は, 後 述の曲げせん断実験の柱の主筋にも用いるSD390規格のD10異形棒 鋼である。試験片数は 5 本で, その見かけの破断強度（破断荷重を 公称断面積で除したもの）は，1.23〜 1.70tf $/ \mathrm{cm}^{2}$ であり，D10 自体の 降伏応力度の $1 / 3$ 程度である。実験室の溶接機とつたない技術で自 作した割には，破断強度は比較的安定したものとなっている。

次に，切断鉄筋の圧縮力伝達能力を調べることを目的に行った単 筋柱の圧縮試験結果について述べる。試験体図を Fig. 3 に示す。試 験体は $12 \times 12 \times 24 \mathrm{~cm}$ の直方体形状て，中心にD13 異形棒鋼が埋 め込まれている。鉄筋は中央部で切断処理を施したものと通常のも のの 2 通りで, これら 2 体の圧縮時の挙動を比較し, 切断鉄筋の圧 縮性能を調べうとしたものである。測定項目は, 荷重, 中央部 $20 \mathrm{~cm}$ 区間の変位, コンクリート表面の軸歪み, 及び切断位置から 6 $\mathrm{cm}$ 離れた筒所の鉄筋の歪みである。当然の事ながら試験体は同一 バッチで練られたコンクリートを用いて作成されている。荷重変位 関係を Fig. 4 に，コンクリートと鉄筋の歪みの関係を Fig. 5 に，変 位と鉄筋の歪みの関係を Fig. 6 に示す。実線が通常の鉄筋を内蔵し た試験体の，点線が切断鉄筋の結果でる。また，Fig. 5,6中の破線 は，平面保持が成立し，付着が完全の場合の縦軸と横軸の関係を示 している。Fig. 4 より，若干剛性が異なるものの最大耐力，その後 の耐力低下の様子に至るまで，通常と切断の両試験体に有意差は認 められない。また，最大耐力を迎える手前では，付着の劣化により， 鉄筋の歪みが, コンクリートの歪みに追従できない現象が共に認め られる（Fig．5）がほほぼ最大耐力時には両鉄筋ともに圧縮降伏し， 変位の增大とともに $1.8 \%$ 程度まで塑性流れを起こしていることが Fig. 6より認められる。本実験より，切断鉄筋は，判性，圧縮力伝 達能力とともに，通常の鉄筋と变才らない性能を有しているといえ る。

\section{3. 通常の鉄筋コンクリート柱との比較実験}

\section{1 試験体及び実験方法}

試験体リストをTable 2に，試験体の形状及び配筋の詳細をFig. 7 に示す。実験は，主筋の配筋を通常の平行配筋としたNシリーズと， 一部の主筋をX形配筋とした X シリーズの 2 つで構成されている。 $N$ シリーズは，通常の鉄筋を 4 隅に平行配筋（全主筋比 $1.11 \%$ ）し た $\mathrm{NN}$ 試験体と， NN 試験体にさらに同量の，柱の両端部近傍で切 断処理した切断鉄筋を付加配筋したNS 試験体の比較実験である。 またXシリーズは， 4 隅の平行配筋に加え， 4 本の通常の鉄筋をX 形に配筋した，即ち全主筋比が $2.22 \%$ XN 試験体亡，X 形に配筋

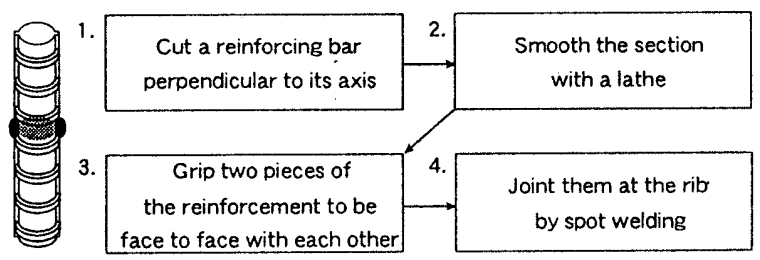

Fig. 2 Making process of severed bar
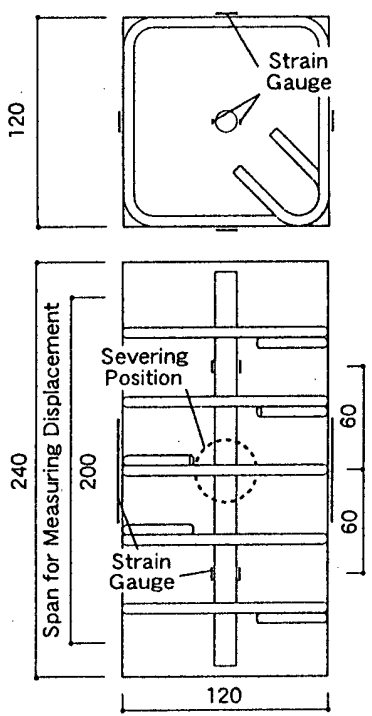

Fig. 3 Dimension and detail of specimen for compression test

Table 1 Mechanical properties of severed bar

\begin{tabular}{c|c|c|c|c|c|c}
\hline \multirow{2}{*}{ Deformed Bar D10 } & \multirow{2}{*}{ Normal Bar } & \multicolumn{5}{|c}{ Severed Bar } \\
\cline { 3 - 8 } & & 1 & 2 & 3 & 4 & 5 \\
\hline Yield Strength $\left(\right.$ tonf $\left./ \mathrm{cm}^{2}\right)$ & 4.72 & \multicolumn{5}{|c}{} \\
\hline Tensile Strength $\left(\right.$ tonf $\left./ \mathrm{cm}^{2}\right)$ & 6.22 & 1.53 & 1.23 & 1.70 & 1.43 & 1.68 \\
\hline
\end{tabular}

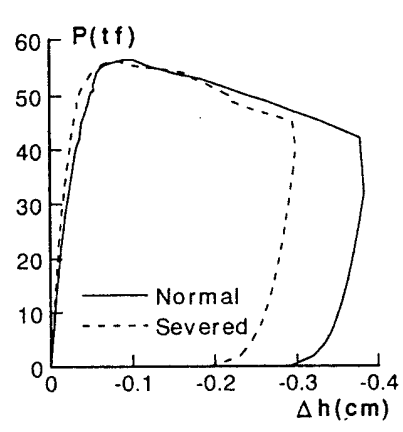

Fig. 4 Load -

axial displacement curves

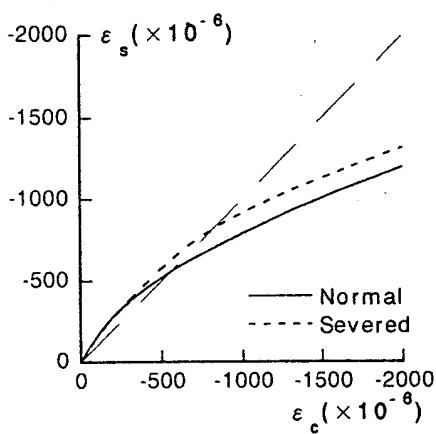

Fig. 5 Strain of steel strain of concrete relations

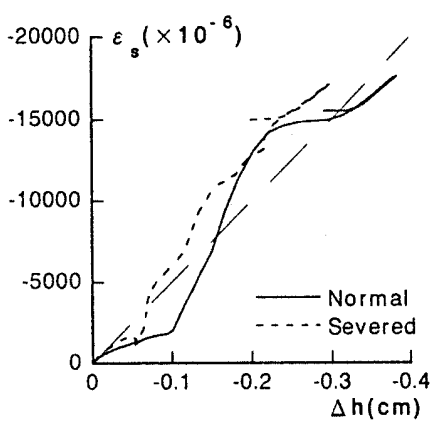

Fig. 6 Strain of steel axial displacement relations 
Table 2 List of specimens for bending test with axial compression

\begin{tabular}{|c|c|c|c|c|c|}
\hline \multicolumn{2}{|c|}{ Specimen } & NN & NS & $\mathrm{XN}$ & $x S$ \\
\hline \multicolumn{2}{|c|}{$\mathrm{b} \times \mathrm{D} \times \mathrm{h}(\mathrm{mm})$} & \multicolumn{4}{|c|}{$160 \times 160 \times 640$} \\
\hline \multirow{3}{*}{$\begin{array}{l}\text { Longitudinal } \\
\text { Reinforcing } \\
\text { Bars }\end{array}$} & Normal Bars & \multicolumn{4}{|c|}{$4-D 10(1.11 \%)$} \\
\hline & \multirow{2}{*}{$\begin{array}{c}\text { Additional } \\
\text { Bars }\end{array}$} & \multirow{2}{*}{ - } & Severed Parallel Bars & Diagonal Bars & Severed Diagonal Bars \\
\hline & & & \multicolumn{3}{|c|}{$4-D 10(1.11 \%)$} \\
\hline \multicolumn{2}{|c|}{ Hoop Reinforcing Bars } & \multicolumn{2}{|c|}{$2-6 \phi @ 30(1.17 \%)$} & \multicolumn{2}{|c|}{$2-6 \phi @ 40(0.88 \%)$} \\
\hline \multicolumn{2}{|c|}{$\begin{array}{c}\text { Compressive Strength } \\
\text { of Concrete } \sigma_{\mathrm{B}}\left(\mathrm{kgf} / \mathrm{cm}^{2}\right)\end{array}$} & 270 & 270 & 315 & 310 \\
\hline \multicolumn{2}{|c|}{ Axial Force $(t f)$} & \multicolumn{2}{|c|}{$32\left(0.46 \mathrm{bD} \sigma_{\mathrm{g}}\right)$} & \multicolumn{2}{|c|}{$40\left(0.50 \mathrm{bD} \sigma_{\mathrm{B}}\right)$} \\
\hline
\end{tabular}
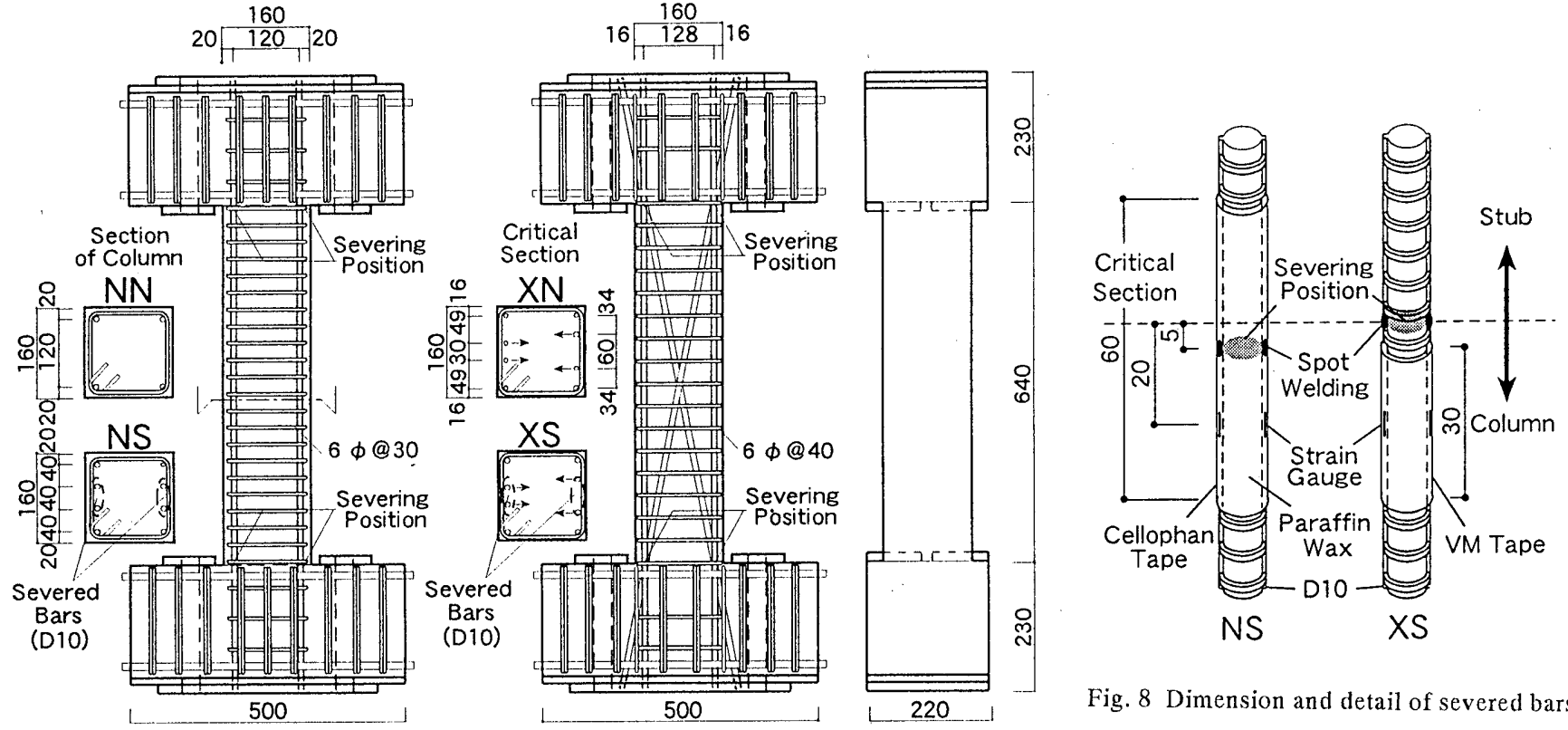

Fig. 8 Dimension and detail of severed bars

Fig. 7 Dimension and detail of specimens for bending test with axial compression

した鉄筋を切断鉄筋に置き換えた XS 試験体の比較実験である。配 筋をX形とした理由は, コンクリート強度に比して主筋が比較的高 強度の SD390規格（降伏応力度 $4.72 \mathrm{tf} / \mathrm{cm}^{2}$, Table 1参照）であった ことと，16cm 角の柱断面に対して， D10という太径の主筋を用いて いたため付着に対する条件が戦しく, 平行配筋では, 付着割裂破壊 を起こす恐れがあったためのみで，他意はない。表に示したコンク リート強度は, いずれも加力実験直後に行った試験体と同一養生条 件のシリンダー強度である。全ての試験体に対して, 定軸力下の繰 り返し逆対称曲げせん断試験を実施した。試験体のシェアスパン比

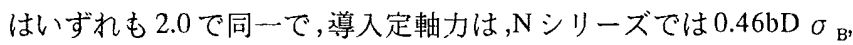
$\mathrm{X}$ シリーズでは $0.50 \mathrm{bD} \sigma_{\mathrm{B}}$ である。また， せん断補強筋比は $\mathrm{N}$ シ

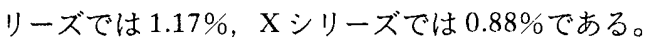

Fig. 8 に切断鉄筋の詳細図を示す。切断位置は，NS 試験体では， 危険断面より柱側 $5 \mathrm{~mm}$ の位置, XS試験体では危険断面とした。歪 みゲージ貼付位置は，危険断面より $20 \mathrm{~mm}$ 柱側に入ったところで， これは切断鉄筋に限らず同様である。また, 切断位置で柱の断面性 能が急変することから, 変形が切断位置に集中し, 付着の程度に よっては引張り鉄筋が破断する恐れがあることから，NS 試験体で は切断位置から雨端 $30 \mathrm{~mm}$, 計 $60 \mathrm{~mm}$ の範囲にパラフィンワックス を㓌付し，付着を除去している。XS 試験体では特に付着除去処理 を施していないが, 歪みゲージ保護のための自己瘉着ビニルテープ (VMテープ) が, ゲージ周辺の約 $30 \mathrm{~mm}$ の範囲に巻かれており, そ

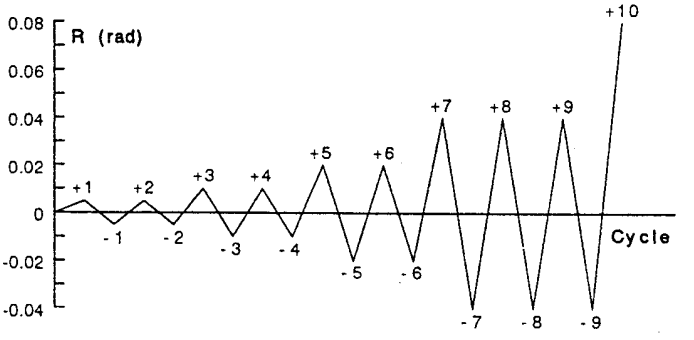

Fig. 9 Loading schedule

の範囲の付着はないものと考えられる。これは，切断鉄筋に限らず 他の鉄筋についてもいえることである。

載荷は, 変形角制御の正負交番であり, 制御変形角はFig. 9 に示 す通りである。但し, 履歷性状が不安定となり, 設定軸力を保持で きなくなった場合は，その時点で加力を終了している。測定項目は, 軸力, 材端モーメント, 材端の回転量, 軸方向変位, 及び, 主筋の 危険断面近傍での軸歪みである。

\section{2 実験結果及び考察}

Fig. 10 に, 両端の材端モーメントの平均值と部材角の関係を示 す。材端モーメントは, 部材座標系で定義されたモーメントであり, $\mathrm{P}$ - $\Delta$ 効果はない。図中の破線は, コンクリートを引張り強度が 0 , 

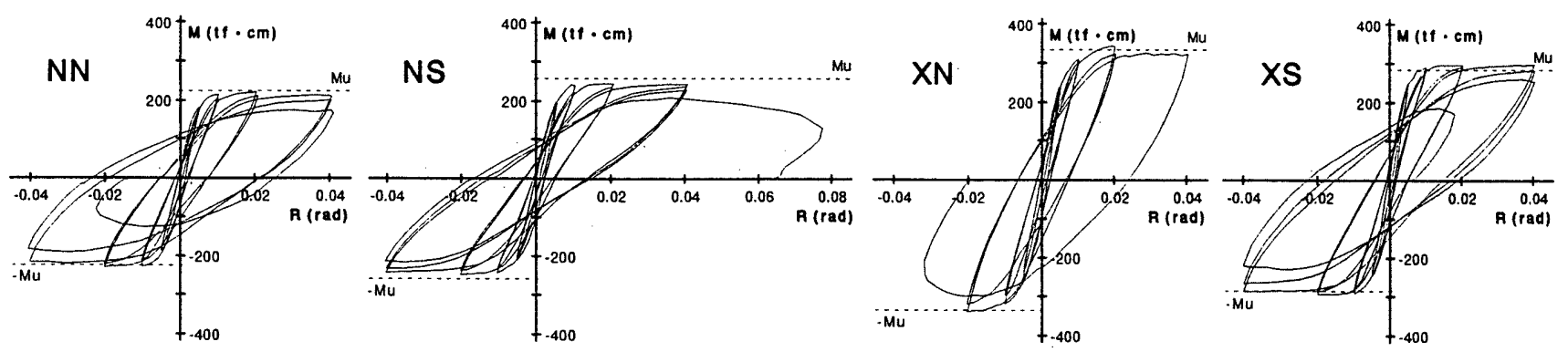

Fig. 10 End moment - end rotation curves
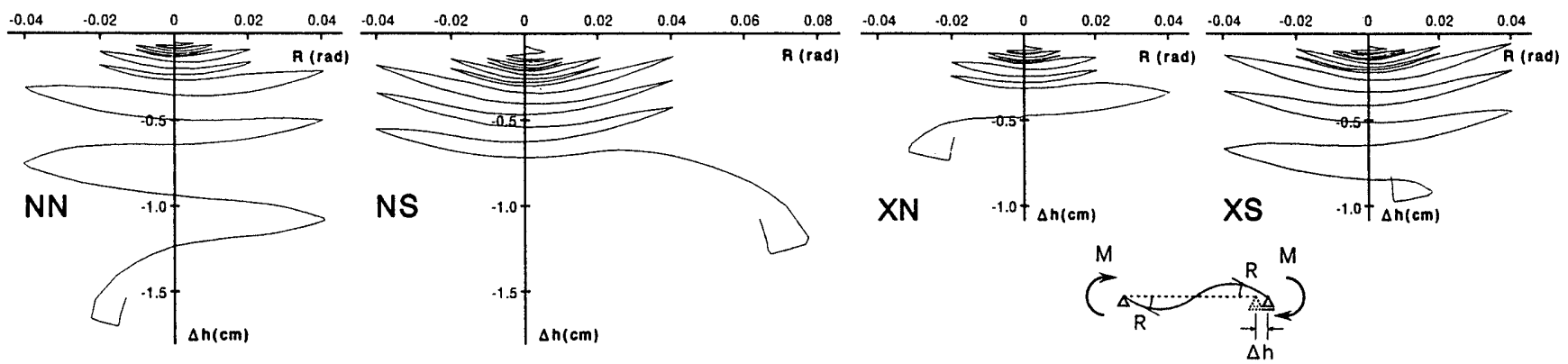

Fig. 11 Axial displacement - end rotation relations

圧縮強度が $\sigma_{\mathrm{B}}$ の剛塑性体，鉄筋を強度が降伏応力度 $\sigma_{y}$ の魝塑性 体, 切断鉄筋を引張り強度が 0 , 圧縮強度が降伏応力度 $\sigma$, の剛塑 性体と仮定したときの断面の曲げ強度の計算值を示している。

載荷計画通りの加力が行えたのはNS試験体のみで, NN試験体は 9 サイクル目の負方向載荷中に, XN試験体は 7 サイクル負側でXS 試験体は最終サイクルでそれぞれ設定軸力を維持できなくなり，載 荷を終了した。しかしながら， Nシリーズ，Xシリーズ共に，切断 鉄筋を用いた NS，XS試験体の方が，明らかに軸方向力に対する安 定性が優れているといえる。Fig. 11 は，各試験体の軸方向縮みの推 移を部材角との関係で示したものである。切断鉄筋を用いた試験体 は, 導入軸力比が $0.46 \mathrm{bD} \sigma_{\mathrm{B}}$, あるいは $0.50 \mathrm{bD} \sigma_{\mathrm{B}}$ と大きいにも関 わらず，各半サイクルで復元力が安定している間は，端部の曲げ降 伏後に軸方向に伸びる挙動を示しており，通常の鉄筋コンクリート 柱試験体に比一，中立軸深さが浅くなっていることが伺える。これ は，曲げを受けたときに，断面が圧縮鉄筋量が多い偏心断面となっ ていることの効果である。曲げを受けているときの切断鉄筋の圧縮 軸力負担分は，鉄筋が圧縮降伏しているとすれば約6.7ffで，これは $\mathrm{N}$ シリーズでは約 $0.1 \mathrm{bD} \sigma_{\mathrm{B}}, \mathrm{X}$ シリーズでは約 $0.09 \mathrm{bD} \sigma_{\mathrm{B}}$ の軸力 比に相当する。この曲げを受けるときのコンクリートの軸力負担の 軽隇が，靯性改善効果をもたらしたものと考えられる。

Fig. 12に, 各半サイクルでの曲げ变形による塑性エネルギー吸収 量の累積值を示す。実線が，通常の鉄筋コンクリート柱試験体を， 点線が切断鉄筋を用いた試験体を表わしている。同サイクルでのエ ネルギー累積值は，曲げ耐力自体が切断鉄筋を用いた試験体の方が 小さいXシリーズでは当然のことではあるが, $N$ シリーズでは切断 鉄筋を付加した試験体の方が曲げ耐力が高いにも関わらず，いずれ も通常の鉄筋コンクリート試験体の方が高い值を示している。復元 力特性（Fig. 10）を見ても，切断鉄筋を用いた場合，履歴ループの 形状が通常の鉄筋コンクリート柱に比べやせている, 特に除荷, 再 載荷域が直線的で，膨らみがないことが伺える。これは，通常の鉄 筋コンクリート柱試験体がコンクリートの压縮塑性化で相当のエネ
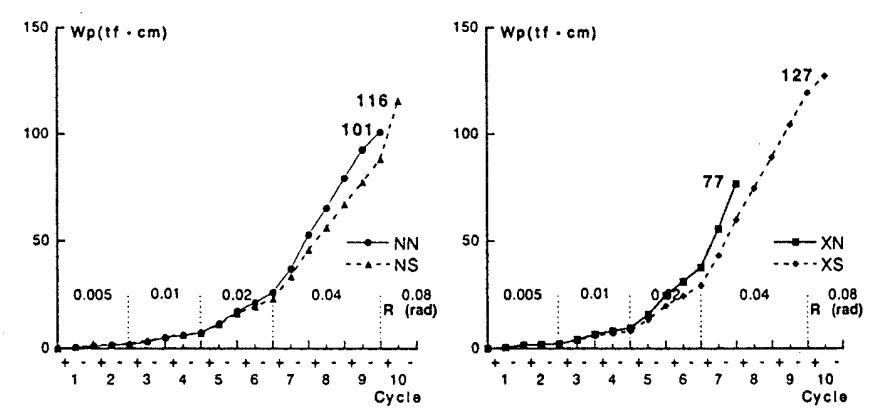

Fig. 12 Accumulated energy absorbed due to bending during each half hysteresis loop

ルギーを吸収しているのに対し，切断鉄筋を用いた場合には鉄筋に よる仕事が主になるためと考元られる。復元力特性は，エネルギー の面から見れば，通常の鉄筋コンクリート柱に比して良好とは言え ないが，柱に求められる最も重要な性能は軸力を安定的に保持する ことであり，エネルギー吸収は他の梁端の塑性ヒンジにまかせてし まえばよいので，大きな欠点とはならない。

Xシリーズの試験体の主筋の歪み履歴の一例をFig. 13に示す。左 より，順に XN 試験体の平行配筋の主筋，X形配筋の主筋， XS 試験 体の平行配筋の主筋， $\mathrm{X}$ 形配筋の切断鉄筋の歪み履歴である。切断 鉄筋は, 制御変形角 $0.01 \mathrm{rad}$ の載荷中に引張り側で破断後, 再圧縮 時には降伏歪みを上回っており, 十分な圧縮力伝達能力があること が認められる。また，引張りと圧綟の繰り返しの中でも，圧縮時の 性能に劣化は認められず，少なくとも本実験に関しては，例えば鉄 筋の軸芯がずれるというような鉄筋の太柄作用がなくなることの悪 影響は見られなかった。XN試験体ては主筋は平行配筋のものも，X 形配筋のものも材端てはほとんど圧縮歪みの領域でぼ同様な挙動 をしているのに対して，XS 試験体の平行配筋の鉄筋, 即ち切断さ れていない鉄筋は，引張り域から圧縮域まてかなり大きな歪み変動 をしており，大きな塑性仕事を為していることが伺える。また本実 験に関する限り，鉄筋に大きな引張り歪み集中は認められなかった。 

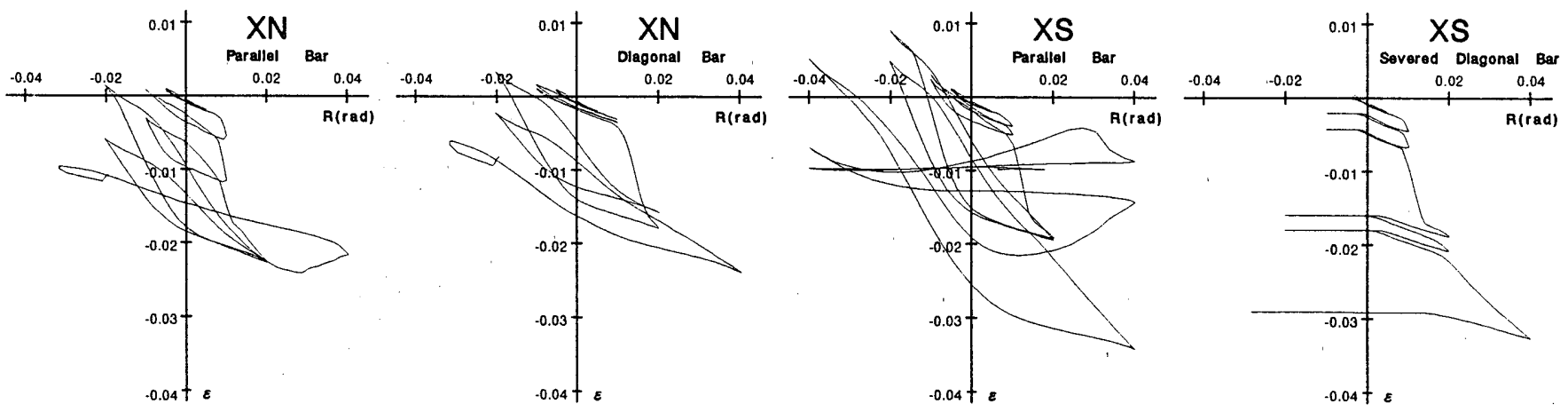

Fig. 13 Several examples of strain of bars - end rotation relations

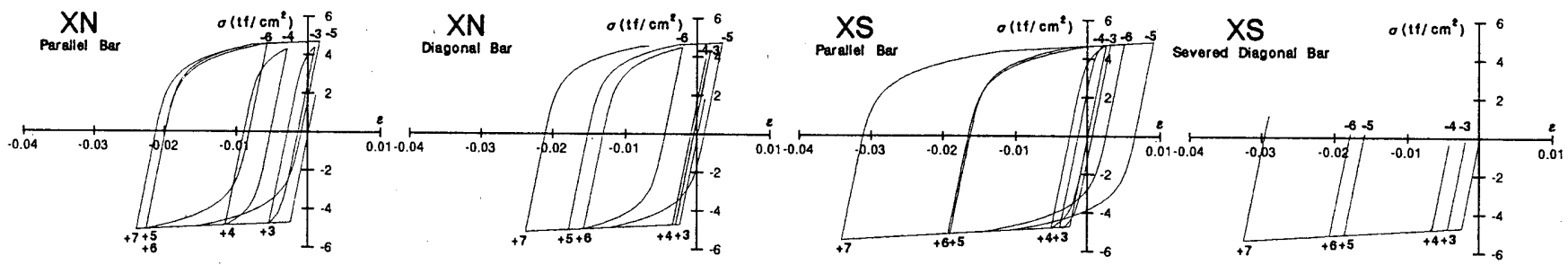

Fig. 14 Stress - strain curves of the bars calculated using the strain histories in Fig. 13

しかしながら，本実験では，使用した鉄筋が断面に対して比較的太 径でかつ高強度であるとから付着に厳しい条件になっていること, 軸力が相当高軸力であることと載荷が正負交番で制御変形角も正負 で等しいことから圧縮時に付着劣化が著しいであろうこと,及び主 筋の歪み測定のために, 若干ではあるがあらかじめ付着がきれてい る部位が存在すること等, 多くの条件が鉄筋の歪み集中に対しては 楽な方向に作用しており,この件については今後も詳細な検討を要 する。その結果, やはり引張り鉄筋への歪み集中が繁しいのであれ ば，その解決策として，NS 試験体で施したように主筋の付着を一 部除去する方法, あるいは, 切断筋を多数配する場合には, 切断位 置を塑性ヒンジ領域内に複数設ける方法を考えている。

Fig. 14は, Fig. 13で示した鉄筋の歪み履歷より計算した鉄筋の応 力一歪み曲線である。鉄筋の応力一䄳み履歴は, 渡辺 ${ }^{4)}$ ら之同様 に, 横尾, 中村 ${ }^{5)}$ のモデルに基づいて, Ramberg-Osgood型の関数 で与えた。ただし, 渡辺 ${ }^{42}$ らと異なり, 降伏棚は考えず，2次勾配 をもつBi-linear 型の応力一歪み関数とし，2 次勾配は, 加藤 ${ }^{6)}$ の研 究に基づいて与えている。切断鉄筋の挙動について見てみると, 各 サイクルの負方向載荷時にほぼ 0 近傍まで応力が低下しており, 計 算結果は信用し得るものと考えられる。本図からも, 切断鉄筋を用 いた試験体の平行配筋した鉄筋が大きな塑性仕事をしているといえ る。

\section{4. 結論}

鉄筋コンクリート柱, 特に内柱の曲げ鞄性を改善する方法として, 危険断面近傍で切断した切断鉄筋を断面に対称付加配筋する手法を 考案し, その有効性を従前の鉄筋コンクリート柱との比較実験によ り検討した。その結果, 以下の知見を得た。

1) 本提案手法で加工した鉄筋は, 目論見よ゙おり, 引張りに弱く, 圧縮力伝達能力は, 通常のそれと变わらない鉄筋となっており, こ の鉄筋を対称付加配筋した柱は, 曲げに対し圧縮鉄筋量の多い（複
筋比が 1 より大きい）偏心配筋断面を有する柱となる。

2 ) 本提案柱は，エネルギー吸収能力という面からみた水平力に対 する復元力特性は，通常の鉄筋コンクリート柱に劣るが，偏心配筋 の効果により, 軸方向力の支持に関する安定性は格段に向上し，そ の結果, 変形能力 (軸力を安定して保持し得る繰り返しの累積変位) は改善される。

ただし，前章末でも述べたが，鉄筋を切断したことによる通常の 鉄筋への引張り歪み集中の問題は未解決であり, 今後の課題とした い。また，本論文で揭げた試験体では，試験方法が逆対称の曲げせ ん断実験であったため，切断鉄筋も柱の全長にわたる通し配筋とし たが, 実際には塑性ヒンジを計画する部位のみに, 必要な付着長さ, 定着長さをとって配筋すれば十分であり, 付加鉄筋量の多さの面は, ハンドリングが通常の主筋と変わらず，せん断補強筋に比べればは るかに簡便であろうことを考え合わせれば,それ程大きなハンディ キャップとはならないであろうと考えている。

\section{参考文献}

1）例えば，六車 㫮，渡辺史夫，他：横補強による高強度コンクリートの 勒性改善に関する研究，第 5 回コンクリート工学年次講演会講演諭文集, pp.317 320, 1983.

2) 堀田久人，安藤秀樹 : 変動軸力を受ける鉄筋コンクリート柱における偏 心配筋の有効性に関方石研究, 日本建築学会大会 (北海道) 学術講演梗概 集 (C - 2 分冊) pp.413 414， 1995.8.

3）倉本 洋, 宮井清忠, 南 宏一, 若林 実: 高仕縮力を受けるX形配筋 柱の強度と靭性、第 8 回コンクリート工学年次講演会論文集, pp.821 $824,1986$.

4）渡辺史夫，大住和正，六車 熙：異種強度軸筋の混使用による $\mathrm{RC}$ 柱断面 曲げ性能の改善, 日本建築学会構造系論文報告集, 第 430 号, pp.41 49, 1991.12

5）横尾義貫，中村恒善，小宮山俊朗，河田康夫：Non-stationary hysteretic uniaxial stress-strain relations of a wide-flange steel, 日本建筑学会諭文報告 集，第 259 号. pp.53〜66，1977.9.

6）加藤大介：配筋法を考慮した鉄筋コンクリート造柱の変形能の評価法, 日本建築学会構造系論文報告集，第 450 号，pp.81 88， 1993.8. 